DR RACHEL M. GWYNNE (Orcid ID : 0000-0002-3545-2045)
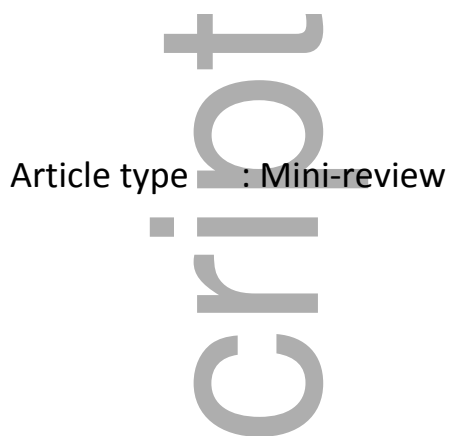

Luminal 5- $\mathrm{HT}_{4}$ Receptors - A Successful Target for Prokinetic Actions

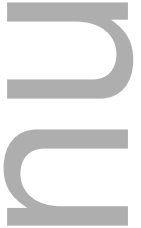

Rachel M Gwynne and Joel C Bornstein

Department of Physiology, University of Melbourne, Parkville, Vic 3010, Australia
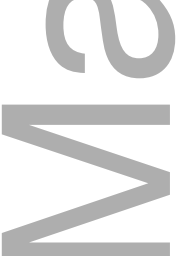

Running title: luminal $5-\mathrm{HT}_{4} \mathrm{Rs}$ as a target for prokinetic agents

Word Count: 2915

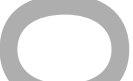

Correspondence to:

R.M. Gwynne

Department of Physiology

University of Melbourne

Parkville, Vic 3010

This is the author manuscript accepted for publication and has undergone full peer review but has not been through the copyediting, typesetting, pagination and proofreading process, which may lead to differences between this version and the Version of Record. Please cite this article as doi: $10.1111 / \mathrm{NM} 0.13708$

This article is protected by copyright. All rights reserved 
Australia

Ph: 61-3-8344-4466

Email: rgwynne@unimelb.edu.au

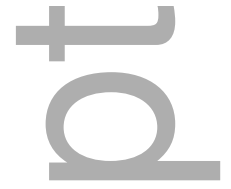

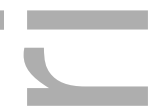

\section{Serotonin and the Enteric Nervous System}

Intestinal propulsion is primarily controlled by the myenteric plexus of the enteric nervous system (ENS) contained within the gut wall (Figure 1). It is also heavily dependent on serotoninergic signalling with pharmacological agents targeting serotonin (5-HT) receptor subtypes used clinically for decades to treat functional bowel disorders causing diarrhea and constipation ${ }^{1-3}$. Shokrollahi et al. (2019) in the current issue of Neurogastroenterology and Motility, examined the effects of luminal prucalopride, a highly specific $5-\mathrm{HT}_{4}$ receptor (5$\mathrm{HT}_{4} \mathrm{R}$ ) agonist used clinically to treat various forms of constipation in humans, on colonic propulsion in the rabbit ${ }^{4}$. In this mini-review we discuss evidence for luminal $5-\mathrm{HT}_{4} \mathrm{Rs}$ as valuable targets for prokinetic agents in facilitating propulsive motor patterns.

The actions and roles of serotonin (5-Hydroxytryptamine, $5-\mathrm{HT}$ ) within the gastrointestinal tract (GIT) have been extensively studied over decades and yet 5-HT signalling is so complex that many questions remain unanswered. This is due to the many different $5-\mathrm{HT}$ receptors and their subtypes found in the gut, their diverse locations and the fact that there are two distinct sources of 5-HT, mucosal and neuronal $1,5,6$. It is well known that $95 \%$ of the body's $5-\mathrm{HT}$ is found in the GIT where approximately $90 \%$ is synthesized and released from specialised mucosal enteroendocrine cells (enterochromaffin, EC) cells. Up to $5 \%$ is found in myenteric serotonergic neurons which, although a small population, have widespread projections suggesting they play a significant role in modulating gut motility ${ }^{7,8}$. The two primary sources of serotonin have different synthetic pathways. In EC cells 5-HT synthesis from L-tryptophan is mediated by the rate-limiting enzyme tryptophan hydroxylase 1 (TPH1), whereas neuronal 5-HT synthesis is mediated TPH2 ${ }^{9-12}$. This has conveniently 
allowed the relative roles of mucosal and neuronal $5-\mathrm{HT}$ in modulating gastrointestinal motility to be investigated, but to this day remains an area surrounded by much controversy. For example, there is continuing debate over the role of $5-\mathrm{HT}_{3}$ receptors in the generation of mouse colonic migrating motor complexes (CMMCs) in vitro where some studies report mucosal 5-HT plays an important role ${ }^{9,13-15}$ and others conclude it is unimportant ${ }^{16-21}$

\section{5-HT ${ }_{4} \mathrm{Rs}$ and Prokinetic agents}

There are 7 different types of $5-\mathrm{HT}$ receptor $\left(5-\mathrm{HT}_{1}-5-\mathrm{HT}_{7}\right)$ some with multiple subtypes ${ }^{22}$. Those identified in the gastrointestinal tract include $5-\mathrm{HT}_{1 \mathrm{~A}}, 5-\mathrm{HT}_{1 \mathrm{P}}, 5-\mathrm{HT}_{2 \mathrm{~A}}, 5-\mathrm{HT}_{2 \mathrm{~B}}, 5-\mathrm{HT}_{3}, 5-$ $\mathrm{HT}_{4}$ and $5-\mathrm{HT}_{7}$ receptors ${ }^{5}$. The G-protein coupled $5-\mathrm{HT}_{4}$ receptor $\left(5-\mathrm{HT}_{4} \mathrm{R}\right)$ is widely studied, primarily because agonists at these receptors have prokinetic effects on intestinal motility. In the human colon $5-\mathrm{HT}_{4} \mathrm{Rs}$ are a therapeutic target for treatment of functional bowel disorders including chronic constipation (CC) and constipation predominant irritable bowel syndrome (IBS-C) ${ }^{23-28}$ whilst in the upper gut $5-\mathrm{HT}_{4} \mathrm{R}$ agonists promote gastric emptying 29,30 and have been used clinically to treat gastroparesis ${ }^{31}$.

Despite the clinical success of $5-\mathrm{HT}_{4} \mathrm{R}$ agonists, their mechanism(s) of action is still being debated. The locations of 5- $\mathrm{HT}_{4} \mathrm{Rs}$ (Figure 1) within the GIT are widespread, including various types of enteric neurons and epithelial cells including 5-HT containing EC cells, plus smooth muscle and interstitial cells of Cajal (ICC). Additional complexity derives from differential $5-\mathrm{HT}_{4} \mathrm{R}$ expression between anatomical regions and between different species. Furthermore, several carboxy-terminal splice variants have been identified which include (a), (b), and (e) isoforms in rats ${ }^{32}(\mathrm{a}),(\mathrm{b}),(\mathrm{e})$, and (f) isoforms in mice ${ }^{32,33}$ and (a), (b), (c), (d), (e), (g), (i) and (n) isoforms in humans (Table 1). Another variant has a 14 residue insertion in the second extracellular loop and is found in human brain tissue $\left(5-\mathrm{HT}_{4(\mathrm{~h})}, \mathrm{Table}\right.$ 1) ${ }^{34}$.

Notwithstanding these complexities, clinical studies in humans and many pharmacological studies in isolated preparations in small animals reveal a common theme: $5-\mathrm{HT}_{4} \mathrm{Rs}$ initiate and/or enhance peristaltic reflexes and/or propulsion. This has been demonstrated in guinea pig ileum ${ }^{35-37}$ and colon ${ }^{38-41}$, mouse ${ }^{42}$, rat ${ }^{38,39,43-45}$ and dog colon ${ }^{46}$ and human jejunum ${ }^{39,47}$ and colon ${ }^{48-51}$. Use of early $5-\mathrm{HT}_{4} \mathrm{R}$ agonists in humans including cisapride, mosapride and tegaserod was limited by their adverse secondary effects on other systems 
following their systemic absorption. For example, cisapride inhibits the human ether-à-gogo related gene ( $h E R G$ ) potassium channel at therapeutic concentrations leading to adverse cardiac electrophysiological events including QT prolongation, ventricular tachycardia and ventricular fibrillation ${ }^{25,52}$. Highly selective $5-\mathrm{HT}_{4} \mathrm{R}$ agonists with improved safety have since been developed. In particular, prucalopride, used by Shokrollahi et al. (2019) to demonstrate prokinetic effects on propulsive motor patterns in rabbit proximal colon, has emerged as a popular and effective therapeutic agent for promoting gut motility.

Prucalopride displays high affinity binding to human $5-\mathrm{HT}_{4(\mathrm{a})}$ and $5-\mathrm{HT}_{4(\mathrm{~b})}$ receptor isoforms 53,54 which is consistent with its clinical success ${ }^{23,49,55-57}$ since these isoforms are expressed in the human colon (Table 1). Other high affinity agonists have also been developed including naronapride (ATI-7505), velusetrag (TD-5108) and YH12852. YH12852 ${ }^{58}$ and naronapride ${ }^{59}$ have high affinity for human $5-\mathrm{HT}_{4(\mathrm{a})}$ and $5-\mathrm{HT}_{4(\mathrm{~b})}$ isoforms respectively and velusetrag (TD-5108) is highly potent at the $5-\mathrm{HT}_{4(\mathrm{c})}$ receptor splice variant ${ }^{60}$. While these drugs are still in development, like prucalopride, they appear to be clinically effective in patients with chronic constipation, with no apparent side effects $25,50,58,60,61$ and they target $5-\mathrm{HT}_{4} \mathrm{R}$ isoforms expressed in the human intestine (Table 1).

\section{Prokinetic effects on propulsive motor patterns}

It is clear from Shokrollahi et al. (2019) that prokinetic effects on colonic propulsive motor patterns in the rabbit can be achieved by luminal application of prucalopride. A key feature of this paper is the insight it provides into how prucalopride augments human colonic motor patterns.

Neurally mediated propagating contractions in the large bowel have been studied in mammals from small rodents to humans and appear to be generated via similar mechanisms ${ }^{62}$. However, several difficulties arise when comparing these motor patterns across different species, including humans. The first relates to the large range of nomenclature used to describe these motor patterns and their myoelectric correlates. These include, but are not limited to, colonic migrating motor complexes (CMMCs, mice), giant migrating contractions (GMCs, dogs, rats), migrating spike bursts (cats), long distance contractions (LDCs, rabbits) peristaltic contractions (guinea-pigs), high amplitude propagating contractions (HAPCs, humans), and repetitive propagating pressure sequences (PPSs, humans). To address this issue it was decided at a consensus meeting to use the term 
"colonic motor complex" to refer to neurogenic repetitive peaks of pressure and/or electrical activity in the colon (eg CMMCs) and "neural peristalsis" to refer to anterograde propulsive movements triggered by distension with liquids or solids in animals (eg peristaltic contractions, LDCs) (See Table $4^{63}$ ). It was also determined at the consensus meeting that HAPCs in humans likely correspond to neural peristalsis and repetitive PPSs likely equate to CMCs in animal colon (See Table $5^{63}$ ). Secondly, the relative contribution of myogenic and neurogenic activity to the propulsive motor patterns in different species needs to be considered. For example, the rabbit colon displays distinct myogenic and neurogenic motor patterns that interact so that the neurogenic colonic migrating motor complex is superimposed on the underlying myogenic rhythmic contractions. The myogenic activity manifests as single fast propagating contractions (FPCs) but formation of clusters of FPCs relies on neural activity. The neurogenic long distance contraction (LDC) is the most forceful circumferential propulsive contraction in rabbit colon ${ }^{64-66}$. Shokrollahi et al. (2019) report that both FPC clusters and LDCs are components of the colonic motor complex at different levels of excitation and both are enhanced by intraluminal prucalopride. Similar interactions between myogenic and neurogenic activity have been described in the human colon ${ }^{67,68}$. In contrast, propulsive colonic motor patterns in guinea-pigs, rats and mice are predominantly neurogenic 62 . Further, there are distinct structural differences in the longitudinal muscle between mice, rats, cats and dogs and rabbit and human colon (Figure 2). The rabbit has a 3-taeniated region in the proximal colon that resembles the structure of the 3-taeniated human colon. The different regions display distinct motor patterns. For example, haustral boundary contractions are specific to the 3-taeniated region of rabbit proximal colon and have also been described in humans. These are slowly propagating ring contractions of the circular muscle occurring at a regular frequency $(0.5 \mathrm{cpm})$ that divide the colon into pockets or haustra (Figure 2). They predominantly propagate anally and are neurally mediated although myogenic activity is also involved $65-67,69$. High resolution manometry (HRM) has emerged as a tool to more accurately define human colonic motor patterns and as a method to diagnose colonic motor dysfunction ${ }^{70}$. High amplitude pressure waves (HAPWs) measured using standard manometry techniques and further characterized using HRM are now termed HAPCs ${ }^{63}$. Although relatively infrequent, these are the dominant propulsive motor pattern in human colon and are probably necessary for defecation. Absence of spontaneous or evoked HAPCs may identify abnormal 
colonic function contributing to constipation ${ }^{71,72}$. Importantly, HRM has identified more frequently occurring simultaneous pressure waves (SPWs) which are difficult to discriminate with standard manometry. SPWs have been shown to contribute to propulsion of luminal contents and gas expulsion and may become of diagnostic value in patients with colonic dysmotility ${ }^{67,71}$. Quan et al. (2017) showed that LDCs and FPCs detected in rabbit colon with HRM are equivalent to human colonic HAPCs and SPWs, respectively 66,67,71,73. Shokrollahi et al. (2019) showed prucalopride enhances both FPCs and LDCs in 3-taeniated rabbit proximal colon. Similarly prucalopride induces HAPCs in humans ${ }^{49}$. HRM has also identified haustral boundary transients in humans that may be the pressure pattern caused by haustral contractions, and equivalent to haustral boundary contractions and associated pressure patterns of rabbit colon $65,67,71,74,75$. These similarities suggest the rabbit colon is a highly translatable model of colonic propulsion in humans, especially when combined with the wealth of knowledge gained from studies of colonic propulsion in mice, rats and guinea pigs.

\section{Mechanisms underlying prokinetic actions of $5-\mathrm{HT}_{4} \mathrm{R}$ agonists}

Understanding how prokinetics achieve their effects depends on identifying their site(s) of action. It is generally accepted that one mechanism involves activation of presynaptic 5$\mathrm{HT}_{4} \mathrm{Rs}$ located on myenteric neurons, the primary neurons controlling intestinal motility. These receptors facilitate neurotransmitter release and enhance peristaltic reflexes augmenting propulsion in guinea-pigs, rats and mice ${ }^{76-80}$. In addition, $5-\mathrm{HT}_{4} \mathrm{Rs}$ mediate slow depolarizations in some myenteric neurons in guinea pig ileum ${ }^{81}$. Both are consistent with 5- $\mathrm{HT}_{4} \mathrm{Rs}$ being coupled to $\mathrm{Gs}$, leading to adenylate cyclase stimulation and increased cAMP production, which depolarizes enteric neurons and facilitates transmitter release. But Shokrollahi et al., and another key study by Hoffman et al. (2012), show luminal $5-\mathrm{HT}_{4} \mathrm{Rs}$ are an alternative and effective target for serotonergic prokinetic agents ${ }^{4,40}$. There are multiple mechanisms by which this might occur including activation of neural pathways controlling motility and also neural and non-neural pathways promoting secretion.

Hoffman et al. (2012) identified 5- $\mathrm{HT}_{4} \mathrm{Rs}$ in the colonic epithelium of mouse, rat, guinea pig, and humans, where they are expressed by 5-HT-containing EC and goblet cells (Figure 1). They found that a $5-\mathrm{HT}_{4} \mathrm{R}$ agonist applied to the colonic mucosa in mice causes a TTXinsensitive increase of $5-\mathrm{HT}$ release that was blocked by a $5-\mathrm{HT}_{4} \mathrm{R}$ antagonist. They also 
showed that direct activation of $5-\mathrm{HT}_{4} \mathrm{Rs}$ on other epithelial cells, including mucous secreting goblet cells, leads to enhanced secretion. These observations are consistent with the intracellular signalling mechanism that follows $5-\mathrm{HT}_{4} \mathrm{R}$ activation and coupling to $\mathrm{Gs}$ as increased CAMP in enterocytes and EC cells causes secretion and sensory mediator release. Release of mucosal 5-HT activates mucosal terminals of intrinsic (and extrinsic) primary afferent neurons to excite peristaltic and secretory reflex pathways. Other studies showing enhanced peristaltic reflexes and propulsion via luminal, but not serosal, application of pharmacological agents including $5-\mathrm{HT}_{4} \mathrm{R}$ agonists, further support this mechanism. These include Shokrollahi et al. (2019), and studies of human ${ }^{39}$, guinea pig ${ }^{40,41}$ and rat ${ }^{44}$ colon showing luminal application of $5-\mathrm{HT}_{4} \mathrm{R}$ agonists increases propulsive activity and peristaltic reflexes.

Despite the tendency to treat the myenteric and submucosal plexuses as separate entities controlling motility and secretion respectively, circuits controlling motility and secretion are interconnected and integrated ${ }^{82-84}$. Activation of neural pathways leading to enhanced propulsion probably also excites neural pathways controlling secretion to increase stool softening and facilitate transit. Furthermore, enhanced secretion leading to distension of the gut wall would in turn activate peristaltic reflexes promoting motility. Thus, increased secretion is another way luminal $5-\mathrm{HT}_{4} \mathrm{Rs}$ might lead to prokinetic effects on colonic motor patterns. 5-HT induces fluid secretion in isolated small and large intestine in small animals and humans. Neuronal and non-neuronal mechanisms are involved and $5-\mathrm{HT}_{4} \mathrm{Rs}$ are implicated in both mechanisms. In rat distal colon, 5-HT elicits secretion via activation of 5$\mathrm{HT}_{4} \mathrm{Rs}$ on colonic epithelial cells and a neurally mediated response to 5-HT occurs via 5$\mathrm{HT}_{3} \mathrm{Rs}^{85,86}$. A similar pattern is seen in guinea pig ileum ${ }^{87,88}$. In contrast, neural 5-HT induced secretion occurs via $5-\mathrm{HT}_{4} \mathrm{Rs}$ in pigs ${ }^{89}$ and humans ${ }^{90}$. In the upper gut, activation of $5-\mathrm{HT}_{4} \mathrm{Rs}$ on mucosal epithelial cells in rat and mouse duodenum mediates 5-HT evoked protective bicarbonate secretion ${ }^{91,92}$. Further, $5-\mathrm{HT}$ release caused by mucosal stroking activates $5-\mathrm{HT}_{4}$ receptors on enteric sensory neurons, evoking a neuronal reflex that stimulates chloride secretion in human jejunum ${ }^{93,94}$. Importantly, 5 -HT also causes secretion via a direct activation of mucosal $5-\mathrm{HT}_{4} \mathrm{Rs}$ on human colonic epithelial cells ${ }^{40,95}$. Thus there are two ways in which luminal $5-\mathrm{HT}_{4} \mathrm{R}$ agonists can target mucosal $5-\mathrm{HT}_{4} \mathrm{Rs}$ to enhance secretion contributing to prokinetic effects on colonic transit: a direct action on colonic epithelial cells 
and an indirect action via release of 5-HT from EC cells which excites neural secretory reflex pathways thereby enhancing chloride secretion. Both mechanisms would complement the $5-\mathrm{HT}_{4} \mathrm{R}$ mediated activation of myenteric neural circuits controlling motility in producing prokinetic effects on intestinal propulsion (Figure 1).

There are few definitive receptor localization studies of $5-\mathrm{HT}_{4} \mathrm{Rs}$ in the gut but their findings show multiple potential targets for $5-\mathrm{HT}_{4} \mathrm{R}$ agonists in achieving prokinetic effects (Figure 1 ). An early study used in vitro receptor autoradiography to identify $5-\mathrm{HT}_{4} \mathrm{R}$ in the myenteric plexus of human and guinea pig colon ${ }^{96}$. More recently, Poole et al. (2006) identified 5-HT receptor immunoreactivity in subpopulations of enteric neurons in guinea-pig small intestine and rat and mouse colon, in particular on myenteric and submucosal intrinsic primary afferent neurons (IPANs) in guinea-pig small intestine ${ }^{97}$. In situ hybridization studies found a similar pattern of $5-\mathrm{HT}_{4} \mathrm{R}$ expression in mouse colon ${ }^{77}$ and expression of 5$\mathrm{HT}_{4(\mathrm{a})} 5-\mathrm{HT}_{4(\mathrm{~b})}, 5-\mathrm{HT}_{4(\mathrm{e})}$ and $5-\mathrm{HT}_{4(\mathrm{f})}$ isoforms in mouse gut. The 5- $\mathrm{HT}_{4(\mathrm{e})}$ and 5- $\mathrm{HT}_{4(\mathrm{f})}$ isoforms were myenteric plexus specific. Ray et al. (2009) found immunoreactivity (IR) for rat 5-HT $4(\mathrm{a})$, $5-\mathrm{HT}_{4(\mathrm{~b})}$ and $5-\mathrm{HT}_{4(\mathrm{c} 1)}$ isoforms throughout the GIT with highest density in the colon ${ }^{98}$. They also found abundant IR for (a) and (b) on enteric neurons in both small and large intestine. Table 1 summarizes molecular studies investigating expression of different $5-\mathrm{HT}_{4} \mathrm{R}$ splice variants in the human GIT and elsewhere. It is clear there are multiple commonly expressed 5-HT ${ }_{4} \mathrm{R}$ isoforms: (a), (b), (c), (g), (i) and (n) are found in the GIT and also in the heart and brain. This has important implications for readily absorbable agents whose actions are designed to target the gut (see below). Thus, the $5-\mathrm{HT}_{4} \mathrm{R}$ localisation studies are consistent with a mechanism whereby activation of presynaptic $5-\mathrm{HT}_{4} \mathrm{Rs}$ on myenteric neurons facilitates transmitter release and also with $5-\mathrm{HT}_{4} \mathrm{R}$ mediated depolarisation of enteric neurons that excites the circuitry. However, the findings of Hoffman et al. (2012) described above, convincingly highlight luminal $5-\mathrm{HT}_{4} \mathrm{Rs}$ on multiple mucosal cell types as other targets for $5-\mathrm{HT}_{4} \mathrm{R}$ agonists in promoting colonic motility (Figure 1 ).

5- $\mathrm{HT}_{4} \mathrm{R}$ expression is also reported on smooth muscle in guinea-pigs, mice, rabbits, dogs and humans $46,77,97,99,100$ (Figure 1). In human colon, activation of $5-\mathrm{HT}_{4} \mathrm{Rs}$ causes relaxation possibly due to smooth muscle receptors ${ }^{101,102}$. Activation of these receptors leads to increased cAMP, decreasing intracellular $\mathrm{Ca}^{2+}$ levels causing relaxation. In rabbit, this occurs via modulation of a plasma membrane $\mathrm{Ca}^{2+}$ ATP-ase pump that removes intracellular 
calcium ${ }^{99}$. It is unclear how smooth muscle $5-\mathrm{HT}_{4} \mathrm{Rs}$ would enhance motility since it is difficult to reconcile widespread smooth muscle relaxation with increased propulsion of luminal content. But the in vivo effects of prucalopride on canine colon are region specific where smooth muscle relaxation occurs distally, but not proximally, and the stimulatory effect via neuronal $5-\mathrm{HT}_{4} \mathrm{Rs}$ proximally induces $\mathrm{GMCs}$. In this scenario $5-\mathrm{HT}_{4} \mathrm{R}$ mediated smooth muscle relaxation distally might facilitate transit ${ }^{46}$.

\section{Future Directions}

The variable affinities of $5-\mathrm{HT}_{4} \mathrm{R}$ agonists and antagonists at individual receptor isoforms and their differential expression in particular organs and tissues (Table 1) complicates pharmacological studies investigating functional roles of $5-\mathrm{HT}_{4} \mathrm{Rs}$. This is a significant consideration for design of future pharmacological agents. $5-\mathrm{HT}_{4} \mathrm{R}$ agonists, including prucalopride, show preferential affinity for particular isoforms ${ }^{53,54}$ (Table 1). This is ideal when designing experimental drugs targeting tissues predominantly expressing a particular splice variant, but whether agents are readily absorbed systemically becomes a key consideration when many $5-\mathrm{HT}_{4} \mathrm{R}$ isoforms are commonly expressed in other tissues. Prucalopride is rapidly absorbed and slowly metabolized in the liver leaving $5 \%$ in the faeces, while $60-65 \%$ of the original dose is eliminated unchanged in the urine. Thus, only a small proportion of any dose reaches the colonic mucosa ${ }^{103}$. This has important mechanistic implications for the prokinetic actions of $5-\mathrm{HT}_{4}$ agonists in humans: via synaptic transmission within the enteric neural circuitry by systemically absorbed drug and/or by luminal actions targeting the colonic mucosal epithelium. Although there is no evidence prucalopride causes serious adverse side effects at off target $5-\mathrm{HT}_{4} \mathrm{Rs}$ in humans, there are many potential sites of action outside the gut where the same receptor isoforms are located, including the CNS (for reviews see ${ }^{104,105}$ ) (Table 1). Indeed, a small proportion of patients receiving prucalopride suffer from headaches in the short-term following commencement of treatment ${ }^{103}$. Thus, development of $5-\mathrm{HT}_{4} \mathrm{R}$ agonists formulated to target and remain in the colonic mucosa, or more rapidly inactivated in the liver, is justified to provide a safer method of delivery.

\section{Conclusions}

Luminal $5-\mathrm{HT}_{4} \mathrm{Rs}$ are a probable and effective target for $5-\mathrm{HT}_{4} \mathrm{R}$ agonists in achieving prokinetic effects on GI motility as demonstrated by Shokrollahi et al. in the current issue. 
Nonetheless prokinetic effects are probably achieved via activation of both luminal $5-\mathrm{HT}_{4} \mathrm{Rs}$ and $5-\mathrm{HT}_{4} \mathrm{Rs}$ within the myenteric circuitry with the relative contribution of each depending on the mode of administration and the pharmacokinetics of individual pharmacological agents.

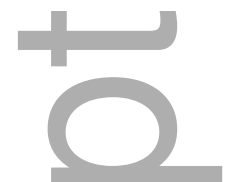

\section{Acknowledgements}

The authors would like to acknowledge the support of the National Health and Medical Research Council of Australia: Grant APP1158952

\section{Author Contributions}

RMG reviewed the literature and wrote the manuscript.

JCB provided advice and performed editorial revisions.

Both authors approved the final version.

\section{Disclosures}

The authors do not have any conflicts of interest to disclose.

\section{References}

1. Gershon MD, Tack J. The serotonin signaling system: from basic understanding to drug development for functional GI disorders. Gastroenterology. Jan 2007;132(1):397-414.

2. Mawe GM, Hoffman JM. Serotonin signalling in the gut--functions, dysfunctions and therapeutic targets. Nature reviews. Gastroenterology \& hepatology. Aug 2013;10(8):473486.

3. Spiller R. Serotonin and GI clinical disorders. Neuropharmacology. Nov 2008;55(6):10721080.

This article is protected by copyright. All rights reserved 
4. Shokrollahi M, Chen JH, Huizinga JD. Intraluminal prucalopride increases propulsive motor activities via luminal 5-HT4 receptors in the rabbit colon. Neurogastroenterology and motility : the official journal of the European Gastrointestinal Motility Society. Apr 23 2019:e13598.

5. Gershon MD. Review article: serotonin receptors and transporters -- roles in normal and abnormal gastrointestinal motility. Alimentary pharmacology \& therapeutics. Nov 2004;20 Supp 7:3-14.

6. Kendig DM, Grider JR. Serotonin and colonic motility. Neurogastroenterology and motility : the official journal of the European Gastrointestinal Motility Society. Jul 2015;27(7):899-905.

7. Okamoto T, Barton MJ, Hennig GW, et al. Extensive projections of myenteric serotonergic neurons suggest they comprise the central processing unit in the colon.

Neurogastroenterology and motility : the official journal of the European Gastrointestinal Motility Society. Apr 2014;26(4):556-570.

8. Neal KB, Parry L, Bornstein JC. Strain-specific genetics, anatomy and function of enteric neural serotonergic pathways in inbred mice. The Journal of physiology. Feb 1 2009;587(3):567-586.

9. Heredia DJ, Gershon MD, Koh SD, Corrigan RD, Okamoto T, Smith TK. Important role of mucosal serotonin in colonic propulsion and peristaltic reflexes: in vitro analyses in mice lacking tryptophan hydroxylase 1. The Journal of physiology. Dec 1 2013;591(23):5939-5957.

10. Li Z, Chalazonitis A, Huang YY, et al. Essential roles of enteric neuronal serotonin in gastrointestinal motility and the development/survival of enteric dopaminergic neurons. The Journal of neuroscience : the official journal of the Society for Neuroscience. Jun 15 2011;31(24):8998-9009.

11. Margolis KG, Stevanovic K, Li Z, et al. Pharmacological reduction of mucosal but not neuronal serotonin opposes inflammation in mouse intestine. Gut. Jun 2014;63(6):928-937.

12. Walther DJ, Peter JU, Bashammakh S, et al. Synthesis of serotonin by a second tryptophan hydroxylase isoform. Science. Jan 3 2003;299(5603):76.

13. Dickson EJ, Heredia DJ, Smith TK. Critical role of 5-HT1A, 5-HT3, and 5-HT7 receptor subtypes in the initiation, generation, and propagation of the murine colonic migrating motor complex. American journal of physiology. Gastrointestinal and liver physiology. Jul 2010;299(1):G144-157.

14. Heredia DJ, Dickson EJ, Bayguinov PO, Hennig GW, Smith TK. Localized release of serotonin (5-hydroxytryptamine) by a fecal pellet regulates migrating motor complexes in murine colon. Gastroenterology. Apr 2009;136(4):1328-1338.

This article is protected by copyright. All rights reserved 
15. Bayguinov PO, Hennig GW, Smith TK. Calcium activity in different classes of myenteric neurons underlying the migrating motor complex in the murine colon. The Journal of physiology. Feb 1 2010;588(Pt 3):399-421.

16. Keating DJ, Spencer NJ. Release of 5-hydroxytryptamine from the mucosa is not required for the generation or propagation of colonic migrating motor complexes. Gastroenterology. Feb 2010;138(2):659-670 670 e651-652.

17. Sia TC, Flack $N$, Robinson $L$, et al. Is serotonin in enteric nerves required for distensionevoked peristalsis and propulsion of content in guinea-pig distal colon? Neuroscience. Jun 14 2013;240:325-335.

18. Sia TC, Whiting M, Kyloh M, et al. 5-HT3 and 5-HT4 antagonists inhibit peristaltic contractions in guinea-pig distal colon by mechanisms independent of endogenous 5-HT. Frontiers in neuroscience. 2013;7:136.

19. Spencer NJ. Constitutively Active 5-HT Receptors: An Explanation of How 5-HT Antagonists Inhibit Gut Motility in Species Where 5-HT is Not an Enteric Neurotransmitter? Frontiers in cellular neuroscience. 2015;9:487.

20. Spencer NJ, Nicholas SJ, Robinson L, et al. Mechanisms underlying distension-evoked peristalsis in guinea pig distal colon: is there a role for enterochromaffin cells? American journal of physiology. Gastrointestinal and liver physiology. Sep 2011;301(3):G519-527.

21. Spencer NJ, Nicholas SJ, Sia TC, Staikopoulos V, Kyloh M, Beckett EA. By what mechanism does ondansetron inhibit colonic migrating motor complexes: does it require endogenous serotonin in the gut wall? Neurogastroenterology and motility : the official journal of the European Gastrointestinal Motility Society. Aug 2013;25(8):677-685.

22. Hoyer D, Clarke DE, Fozard JR, et al. International Union of Pharmacology classification of receptors for 5-hydroxytryptamine (Serotonin). Pharmacological reviews. Jun 1994;46(2):157-203.

23. Bassotti G, Usai Satta P, Bellini M. Prucalopride for the treatment of constipation: a view from 2015 and beyond. Expert review of gastroenterology \& hepatology. Mar 2019;13(3):257-262.

24. Johanson JF, Wald A, Tougas $G$, et al. Effect of tegaserod in chronic constipation: a randomized, double-blind, controlled trial. Clinical gastroenterology and hepatology : the official clinical practice journal of the American Gastroenterological Association. Sep 2004;2(9):796-805. 
25. Manabe N, Wong BS, Camilleri M. New-generation 5-HT4 receptor agonists: potential for treatment of gastrointestinal motility disorders. Expert opinion on investigational drugs. Jun 2010;19(6):765-775.

26. McLaughlin J, Houghton LA. The rationale, efficacy and safety evidence for tegaserod in the treatment of irritable bowel syndrome. Expert opinion on drug safety. Mar 2006;5(2):313327

27. Muller-Lissner SA. Treatment of chronic constipation with cisapride and placebo. Gut. Aug 1987;28(8):1033-1038.

28. Curran MP, Robinson DM. Mosapride in gastrointestinal disorders. Drugs. 2008;68(7):981991

29. Hegde SS, Wong AG, Perry MR, et al. 5-HT4 receptor mediated stimulation of gastric emptying in rats. Naunyn-Schmiedeberg's archives of pharmacology. Jun 1995;351(6):589595.

30. Tanaka T, Mizumoto A, Mochiki E, Suzuki H, Itoh Z, Omura S. Effects of EM574 and cisapride on gastric contractile and emptying activity in normal and drug-induced gastroparesis in dogs. The Journal of pharmacology and experimental therapeutics. Nov 1998;287(2):712719.

31. Johnson AG. The effects of cisapride on antroduodenal co-ordination and gastric emptying. Scandinavian journal of gastroenterology. Supplement. 1989;165:36-43.

32. Claeysen S, Sebben M, Becamel C, Bockaert J, Dumuis A. Novel brain-specific 5-HT4 receptor splice variants show marked constitutive activity: role of the C-terminal intracellular domain. Molecular pharmacology. May 1999;55(5):910-920.

33. Claeysen S, Faye P, Sebben M, Taviaux S, Bockaert J, Dumuis A. 5-HT4 receptors: cloning and expression of new splice variants. Annals of the New York Academy of Sciences. Dec 15 1998;861:49-56.

34. Bender E, Pindon A, van Oers I, et al. Structure of the human serotonin 5-HT4 receptor gene and cloning of a novel 5-HT4 splice variant. Journal of neurochemistry. Feb 2000;74(2):478489.

35. Buchheit $\mathrm{KH}$, Buhl T. Prokinetic benzamides stimulate peristaltic activity in the isolated guinea pig ileum by activation of 5-HT4 receptors. European journal of pharmacology. Nov 26 1991;205(2):203-208.

36. Gwynne RM, Clarke AJ, Furness JB, Bornstein JC. Both exogenous 5-HT and endogenous 5$\mathrm{HT}$, released by fluoxetine, enhance distension evoked propulsion in guinea-pig ileum in vitro. Frontiers in neuroscience. 2014;8:301.

This article is protected by copyright. All rights reserved 
37. Craig DA, Clarke DE. Peristalsis evoked by $5-\mathrm{HT}$ and renzapride: evidence for putative $5-\mathrm{HT} 4$ receptor activation. British journal of pharmacology. Mar 1991;102(3):563-564.

38. Foxx-Orenstein AE, Jin JG, Grider JR. 5-HT4 receptor agonists and delta-opioid receptor antagonists act synergistically to stimulate colonic propulsion. The American journal of physiology. Nov 1998;275(5):G979-983.

39. Grider JR, Foxx-Orenstein AE, Jin JG. 5-Hydroxytryptamine4 receptor agonists initiate the peristaltic reflex in human, rat, and guinea pig intestine. Gastroenterology. Aug 1998;115(2):370-380.

40. Hoffman JM, Tyler K, MacEachern SJ, et al. Activation of colonic mucosal 5-HT(4) receptors accelerates propulsive motility and inhibits visceral hypersensitivity. Gastroenterology. Apr 2012;142(4):844-854 e844.

41. Jin JG, Foxx-Orenstein AE, Grider JR. Propulsion in guinea pig colon induced by 5hydroxytryptamine (HT) via 5-HT4 and 5-HT3 receptors. The Journal of pharmacology and experimental therapeutics. Jan 1999;288(1):93-97.

42. Grider JR. Neurotransmitters mediating the intestinal peristaltic reflex in the mouse. The Journal of pharmacology and experimental therapeutics. Nov 2003;307(2):460-467.

43. Grider JR. Desensitization of the peristaltic reflex induced by mucosal stimulation with the selective 5-HT4 agonist tegaserod. American journal of physiology. Gastrointestinal and liver physiology. Feb 2006;290(2):G319-327.

44. Grider JR, Kuemmerle JF, Jin JG. 5-HT released by mucosal stimuli initiates peristalsis by activating 5-HT4/5-HT1p receptors on sensory CGRP neurons. The American journal of physiology. May 1996;270(5 Pt 1):G778-782.

45. Kadowaki M, Wang XO, Shimatani H, Yoneda S, Takaki M. 5-HT4 receptor enhances the propulsive power of the peristaltic reflex in the rat distal colon. Autonomic neuroscience : basic \& clinical. Jul 31 2002;99(1):62-65.

46. Briejer MR, Prins NH, Schuurkes JA. Effects of the enterokinetic prucalopride (R093877) on colonic motility in fasted dogs. Neurogastroenterology and motility : the official journal of the European Gastrointestinal Motility Society. Oct 2001;13(5):465-472.

47. Foxx-Orenstein AE, Kuemmerle JF, Grider JR. Distinct 5-HT receptors mediate the peristaltic reflex induced by mucosal stimuli in human and guinea pig intestine. Gastroenterology. Nov 1996;111(5):1281-1290.

48. Manini ML, Camilleri M, Goldberg M, et al. Effects of Velusetrag (TD-5108) on gastrointestinal transit and bowel function in health and pharmacokinetics in health and 
constipation. Neurogastroenterology and motility : the official journal of the European Gastrointestinal Motility Society. Jan 2010;22(1):42-49, e47-48.

49. Miner PB, Jr., Camilleri M, Burton D, et al. Prucalopride induces high-amplitude propagating contractions in the colon of patients with chronic constipation: a randomized study. Neurogastroenterology and motility : the official journal of the European Gastrointestinal Motility Society. Sep 2016;28(9):1341-1348.

50. Shin A, Camilleri M, Kolar G, Erwin P, West CP, Murad MH. Systematic review with metaanalysis: highly selective 5-HT4 agonists (prucalopride, velusetrag or naronapride) in chronic constipation. Alimentary pharmacology \& therapeutics. Feb 2014;39(3):239-253.

51. Bouras EP, Camilleri M, Burton DD, McKinzie S. Selective stimulation of colonic transit by the benzofuran 5HT4 agonist, prucalopride, in healthy humans. Gut. May 1999;44(5):682-686.

52. Mohammad S, Zhou Z, Gong Q, January CT. Blockage of the HERG human cardiac K+ channel by the gastrointestinal prokinetic agent cisapride. The American journal of physiology. Nov 1997;273(5):H2534-2538.

53. Briejer MR, Bosmans JP, Van Daele $P$, et al. The in vitro pharmacological profile of prucalopride, a novel enterokinetic compound. European journal of pharmacology. Jun 29 2001;423(1):71-83.

54. Irving HR, Tochon-Danguy N, Chinkwo KA, et al. Investigations into the binding affinities of different human 5-HT4 receptor splice variants. Pharmacology. 2010;85(4):224-233.

55. Omer A, Quigley EMM. An update on prucalopride in the treatment of chronic constipation. Therapeutic advances in gastroenterology. Nov 2017;10(11):877-887.

56. Vijayvargiya $\mathrm{P}$, Camilleri M. Use of prucalopride in adults with chronic idiopathic constipation. Expert review of clinical pharmacology. Jul 2019;12(7):579-589.

57. Wong BS, Manabe N, Camilleri M. Role of prucalopride, a serotonin (5-HT(4)) receptor agonist, for the treatment of chronic constipation. Clinical and experimental gastroenterology. 2010;3:49-56.

58. Jeong EJ, Chung SY, Hong HN, Oh SW, Sim JY. The novel, potent and highly selective 5-HT4 receptor agonist $\mathrm{YH} 12852$ significantly improves both upper and lower gastrointestinal motility. British journal of pharmacology. Feb 2018;175(3):485-500.

59. Camilleri M, Vazquez-Roque MI, Burton D, et al. Pharmacodynamic effects of a novel prokinetic 5-HT receptor agonist, ATI-7505, in humans. Neurogastroenterology and motility : the official journal of the European Gastrointestinal Motility Society. Jan 2007;19(1):30-38.

60. Bassotti G, Gambaccini D, Bellini M. Velusetrag for the treatment of chronic constipation. Expert opinion on investigational drugs. Aug 2016;25(8):985-990. 
61. Jiang $C, X u Q$, Wen $X$, Sun $H$. Current developments in pharmacological therapeutics for chronic constipation. Acta pharmaceutica Sinica. B. Jul 2015;5(4):300-309.

62. Smith TK, Park KJ, Hennig GW. Colonic migrating motor complexes, high amplitude propagating contractions, neural reflexes and the importance of neuronal and mucosal serotonin. Journal of neurogastroenterology and motility. Oct 30 2014;20(4):423-446.

63. Corsetti $M$, Costa $M$, Bassotti $G$, et al. First translational consensus on terminology and definitions of colonic motility in animals and humans studied by manometric and other techniques. Nature reviews. Gastroenterology \& hepatology. Jul 112019.

64. Dinning PG, Wiklendt L, Omari T, et al. Neural mechanisms of peristalsis in the isolated rabbit distal colon: a neuromechanical loop hypothesis. Frontiers in neuroscience. 2014;8:75.

65. Lentle RG, Janssen PW, Asvarujanon P, Chambers P, Stafford KJ, Hemar Y. High-definition spatiotemporal mapping of contractile activity in the isolated proximal colon of the rabbit. Journal of comparative physiology. B, Biochemical, systemic, and environmental physiology. Mar 2008;178(3):257-268.

66. Dinning PG, Costa M, Brookes SJ, Spencer NJ. Neurogenic and myogenic motor patterns of rabbit proximal, mid, and distal colon. American journal of physiology. Gastrointestinal and liver physiology. Jul 2012;303(1):G83-92.

67. Chen JH, Yu Y, Yang Z, et al. Intraluminal pressure patterns in the human colon assessed by high-resolution manometry. Scientific reports. Feb 20 2017;7:41436.

68. Dinning PG, Szczesniak MM, Cook IJ. Proximal colonic propagating pressure waves sequences and their relationship with movements of content in the proximal human colon. Neurogastroenterology and motility : the official journal of the European Gastrointestinal Motility Society. May 2008;20(5):512-520.

69. Quan X, Yang Z, Xue M, Chen JH, Huizinga JD. Relationships between motor patterns and intraluminal pressure in the 3 -taeniated proximal colon of the rabbit. Scientific reports. Feb 14 2017;7:42293.

70. Dinning PG. A new understanding of the physiology and pathophysiology of colonic motility? Neurogastroenterology and motility : the official journal of the European Gastrointestinal Motility Society. Nov 2018;30(11):e13395.

71. Chen JH, Parsons SP, Shokrollahi M, et al. Characterization of Simultaneous Pressure Waves as Biomarkers for Colonic Motility Assessed by High-Resolution Colonic Manometry. Frontiers in physiology. 2018;9:1248.

72. Bampton PA, Dinning PG, Kennedy ML, Lubowski DZ, deCarle D, Cook IJ. Spatial and temporal organization of pressure patterns throughout the unprepared colon during 
spontaneous defecation. The American journal of gastroenterology. Apr 2000;95(4):10271035.

73. Hagger R, Kumar D, Benson M, Grundy A. Periodic colonic motor activity identified by 24-h pancolonic ambulatory manometry in humans. Neurogastroenterology and motility : the official journal of the European Gastrointestinal Motility Society. Jun 2002;14(3):271-278.

74. Ehrlein $\mathrm{HJ}$, Reich $\mathrm{H}$, Schwinger $\mathrm{M}$. Physiological significance of the contractions of the rabbit proximal colon. Quarterly journal of experimental physiology. Jul 1982;67(3):407-417.

75. Ehrlein HJ, Reich H, Schwinger M. Colonic motility and transit of digesta during hard and soft faeces formation in rabbits. The Journal of physiology. May 1983;338:75-86.

76. Galligan JJ, Pan H, Messori E. Signalling mechanism coupled to 5-hydroxytryptamine4 receptor-mediated facilitation of fast synaptic transmission in the guinea-pig ileum myenteric plexus. Neurogastroenterology and motility : the official journal of the European Gastrointestinal Motility Society. Oct 2003;15(5):523-529.

77. Liu M, Geddis MS, Wen Y, Setlik W, Gershon MD. Expression and function of 5-HT4 receptors in the mouse enteric nervous system. American journal of physiology. Gastrointestinal and liver physiology. Dec 2005;289(6):G1148-1163.

78. Pan H, Galligan JJ. $5-\mathrm{HT} 1 \mathrm{~A}$ and $5-\mathrm{HT} 4$ receptors mediate inhibition and facilitation of fast synaptic transmission in enteric neurons. The American journal of physiology. Feb 1994;266(2 Pt 1):G230-238.

79. Ren J, Zhou X, Galligan JJ. 5-HT4 receptor activation facilitates recovery from synaptic rundown and increases transmitter release from single varicosities of myenteric neurons. American journal of physiology. Gastrointestinal and liver physiology. Jun 2008;294(6):G1376-1383.

80. Tonini M, Galligan JJ, North RA. Effects of cisapride on cholinergic neurotransmission and propulsive motility in the guinea pig ileum. Gastroenterology. May 1989;96(5 Pt 1):12571264.

81. Monro RL, Bornstein JC, Bertrand PP. Slow excitatory post-synaptic potentials in myenteric $\mathrm{AH}$ neurons of the guinea-pig ileum are reduced by the 5-hydroxytryptamine7 receptor antagonist SB 269970. Neuroscience. 2005;134(3):975-986.

82. Okamoto T, Bayguinov PO, Broadhead MJ, Smith TK. $\mathrm{Ca}(2+)$ transients in submucous neurons during the colonic migrating motor complex in the isolated murine large intestine. Neurogastroenterology and motility : the official journal of the European Gastrointestinal Motility Society. Aug 2012;24(8):769-778, e354. 
83. Spiller R. Role of motility in chronic diarrhoea. Neurogastroenterology and motility : the official journal of the European Gastrointestinal Motility Society. Dec 2006;18(12):10451055.

84. Kordasti S, Sapnara M, Thomas EA, et al. Effects of cholera toxin on the potential difference and motor responses induced by distension in the rat proximal small intestine in vivo. American journal of physiology. Gastrointestinal and liver physiology. May 2006;290(5):G948-958.

85. Budhoo MR, Harris RP, Kellum JM. 5-Hydroxytryptamine-induced Cl-transport is mediated by 5-HT3 and 5-HT4 receptors in the rat distal colon. European journal of pharmacology. Mar 7 1996;298(2):137-144.

86. Ning $Y$, Zhu JX, Chan HC. Regulation of ion transport by 5-hydroxytryptamine in rat colon. Clinical and experimental pharmacology \& physiology. Jul 2004;31(7):424-428.

87. Scott CM, Bunce KT, Spraggs CF. Investigation of the 5-hydroxytryptamine receptor mediating the 'maintained' short-circuit current response in guinea-pig ileal mucosa. British journal of pharmacology. Aug 1992;106(4):877-882.

88. Cooke HJ, Wang YZ, Frieling T, Wood JD. Neural 5-hydroxytryptamine receptors regulate chloride secretion in guinea pig distal colon. The American journal of physiology. Nov 1991;261(5 Pt 1):G833-840.

89. Hansen MB, Thorboll JE, Christensen P, Bindslev N, Skadhauge E. Serotonin-induced shortcircuit current in pig jejunum. Zentralblatt fur Veterinarmedizin. Reihe A. Mar 1994;41(2):110-120.

90. Borman RA, Burleigh DE. Evidence for the involvement of a 5-HT4 receptor in the secretory response of human small intestine to 5-HT. British journal of pharmacology. Nov 1993;110(3):927-928.

91. Tuo BG, Sellers Z, Paulus P, Barrett KE, Isenberg JI. 5-HT induces duodenal mucosal bicarbonate secretion via cAMP- and Ca2+-dependent signaling pathways and 5-HT4 receptors in mice. American journal of physiology. Gastrointestinal and liver physiology. Mar 2004;286(3):G444-451.

92. Safsten B, Sjoblom M, Flemstrom G. Serotonin increases protective duodenal bicarbonate secretion via enteric ganglia and a 5-HT4-dependent pathway. Scandinavian journal of gastroenterology. Nov 2006;41(11):1279-1289.

93. Budhoo MR, Harris RP, Kellum JM. The role of the 5-HT4 receptor in $\mathrm{Cl}$ - secretion in human jejunal mucosa. European journal of pharmacology. Oct 24 1996;314(1-2):109-114. 
94. Kellum JM, Albuquerque FC, Stoner MC, Harris RP. Stroking human jejunal mucosa induces 5- $\mathrm{HT}$ release and $\mathrm{Cl}$ - secretion via afferent neurons and 5-HT4 receptors. The American journal of physiology. Sep 1999;277(3):G515-520.

95. Borman RA, Burleigh DE. Human colonic mucosa possesses a mixed population of 5-HT receptors. European journal of pharmacology. Aug 15 1996;309(3):271-274.

96. Sakurai-Yamashita Y, Yamashita K, Kaibara M, Enjoji A, Kanematsu T, Taniyama K. Differential distribution of 5-hydroxytryptamine3 receptor in the colon between human and guinea pig. The Chinese journal of physiology. Sep 30 1999;42(3):195-198.

97. Poole DP, Xu B, Koh SL, et al. Identification of neurons that express 5-hydroxytryptamine4 receptors in intestine. Cell and tissue research. Sep 2006;325(3):413-422.

98. Ray AM, Kelsell RE, Houp JA, et al. Identification of a novel 5-HT(4) receptor splice variant ( $\mathrm{r5}-\mathrm{HT}(4 \mathrm{c} 1))$ and preliminary characterisation of specific 5-HT(4a) and 5-HT(4b) receptor antibodies. European journal of pharmacology. Feb 14 2009;604(1-3):1-11.

99. Willenbucher RF, Xie YN, Eysselein VE, Snape WJ, Jr. Mechanisms of cAMP-mediated relaxation of distal circular muscle in rabbit colon. The American journal of physiology. Jan 1992;262(1 Pt 1):G159-164.

100. Sakurai-Yamashita Y, Yamashita K, Kanematsu T, Taniyama K. Localization of the 5-HT(4) receptor in the human and the guinea pig colon. European journal of pharmacology. Nov 3 1999;383(3):281-285.

101. McLean PG, Coupar IM. Stimulation of cyclic AMP formation in the circular smooth muscle of human colon by activation of 5-HT4-like receptors. British journal of pharmacology. Jan 1996;117(2):238-239.

102. Tam FS, Hillier K, Bunce KT. Characterization of the 5-hydroxytryptamine receptor type involved in inhibition of spontaneous activity of human isolated colonic circular muscle. British journal of pharmacology. Sep 1994;113(1):143-150.

103. Tack J, Corsetti M. Prucalopride: evaluation of the pharmacokinetics, pharmacodynamics, efficacy and safety in the treatment of chronic constipation. Expert opinion on drug metabolism \& toxicology. Oct 2012;8(10):1327-1335.

104. Bockaert J, Claeysen S, Compan V, Dumuis A. 5-HT(4) receptors: history, molecular pharmacology and brain functions. Neuropharmacology. Nov 2008;55(6):922-931.

105. Langlois M, Fischmeister R. 5-HT4 receptor ligands: applications and new prospects. Journal of medicinal chemistry. Jan 30 2003;46(3):319-344. 


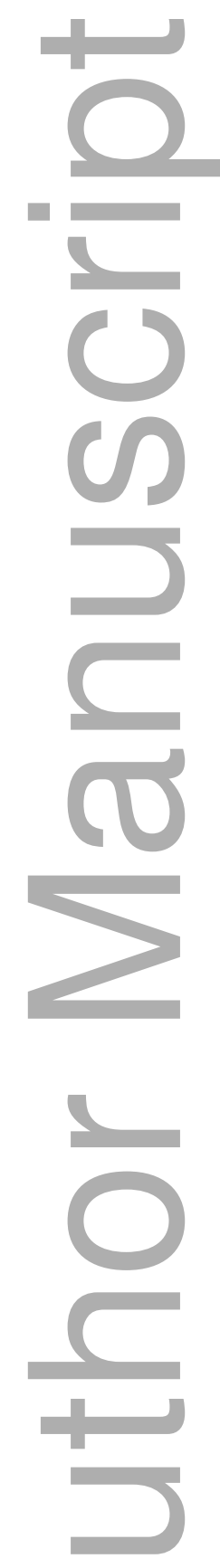

Figure 1. Schematic diagram showing the layers of the intestinal wall (colon) in crosssection demonstrating known locations of $5-\mathrm{HT}_{4} \mathrm{Rs}$ (yellow triangles) from studies performed in mice, rats, guinea-pigs and humans.

Luminal targets for prokinetic agents targeting $5-\mathrm{HT}_{4} \mathrm{Rs}$ include $\mathrm{EC}$ cells (red), colonic enterocytes (green) and goblet cells (pale blue)(see legend). Activation of $5-\mathrm{HT}_{4} \mathrm{Rs}$ on EC 
cells leads to basal 5-HT release exciting mucosal terminals of myenteric and submucosal intrinsic primary afferent neurons which then activate peristaltic and secretory reflex pathways promoting motility. $5-\mathrm{HT}_{4} \mathrm{R}$ activation on enterocytes and goblet cells leads to enhanced luminal $\mathrm{Cl}^{-}$and mucous secretion respectively, softening stool composition and facilitating transit. Activation of presynaptic $5-\mathrm{HT}_{4} \mathrm{Rs}$ on myenteric neurons facilitates neurotransmitter release in ascending excitatory pathways and at the neuromuscular junction enhancing peristaltic reflexes and propulsion. Direct activation of $5-\mathrm{HT}_{4} \mathrm{Rs}$ on enteric neurons causes neuron depolarisation and further excitation within the circuitry. Due to a lack of definitive data on locations of $5-\mathrm{HT}_{4} \mathrm{Rs}$ in descending pathways no labelling is shown.

SMP -submucosal plexus, CM-circular muscle layer, MP-myenteric plexus, LM-longitudinal muscle layer, IPAN-intrinsic primary afferent neuron, IN-interneuron, SMN-secretomotor neuron, $\mathrm{CMMN}$-circular muscle motor neuron, $\mathrm{LMMN}$-longitudinal muscle motor neuron, Eexcitatory, I-inhibitory

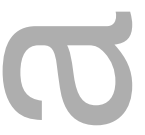

Figure 2. Differences in anatomical structure of the colon in mice, rabbits and humans.

The structure of the longitudinal muscle coat in rabbit and human colon (middle and bottom panels) is different from that in mice (top panel) and other species. The rabbit has a 3taeniated region in the proximal colon that resembles the structure of the 3-taeniated human colon. Haustral boundary contractions specific to this 3-taeniated region divide the colon into pockets or "haustra" and have also been described in humans. The mouse colon is un-taeniated and resembles the distal colon of the rabbit.

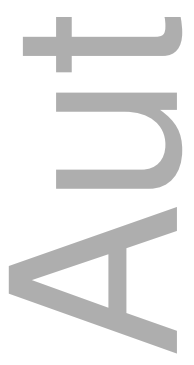

This article is protected by copyright. All rights reserved 


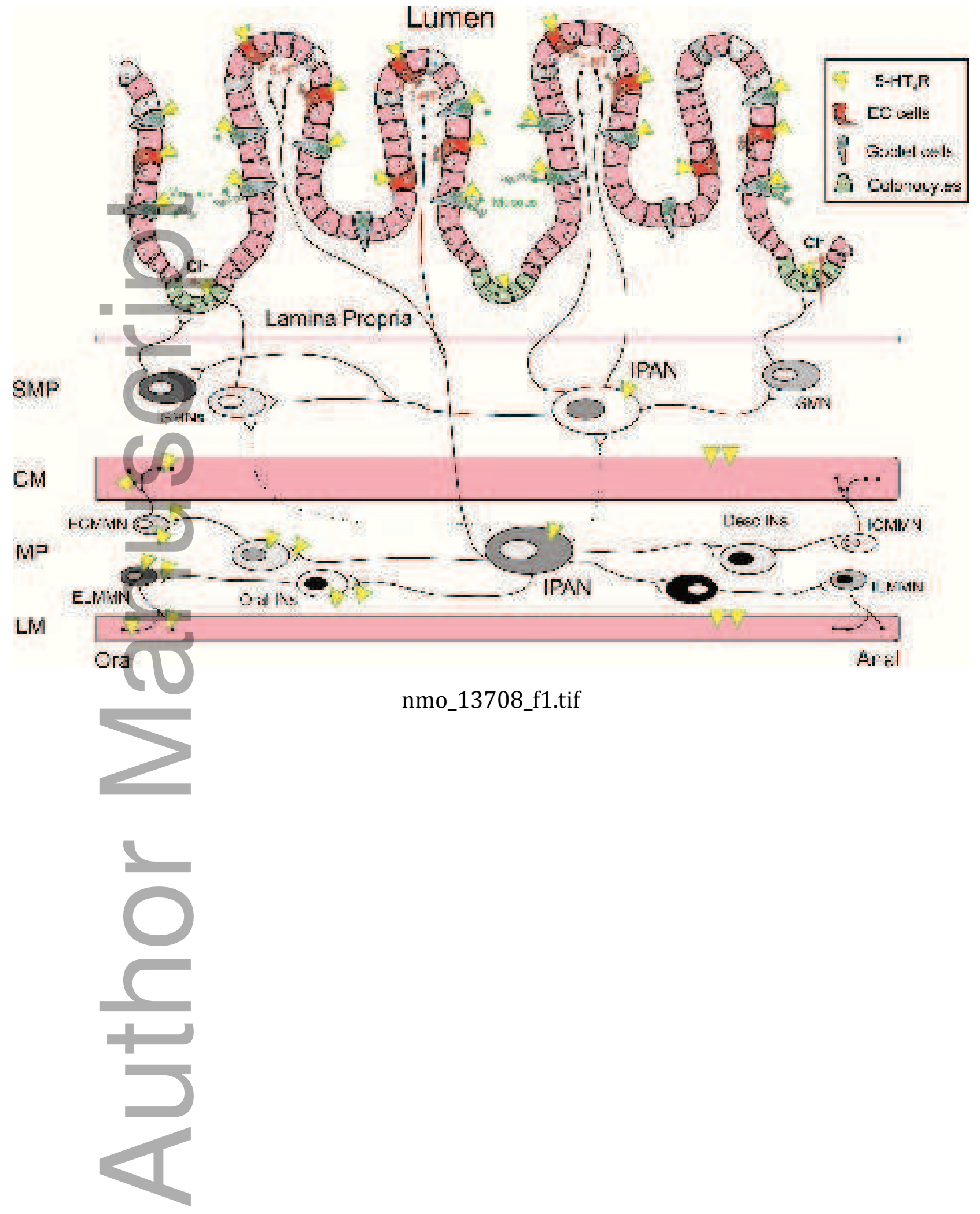

This article is protected by copyright. All rights reserved 


\section{MOUSE}

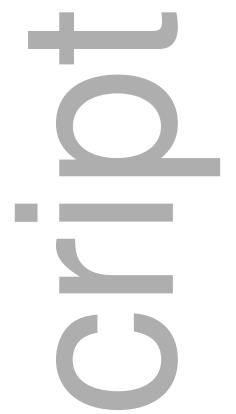

RABBII
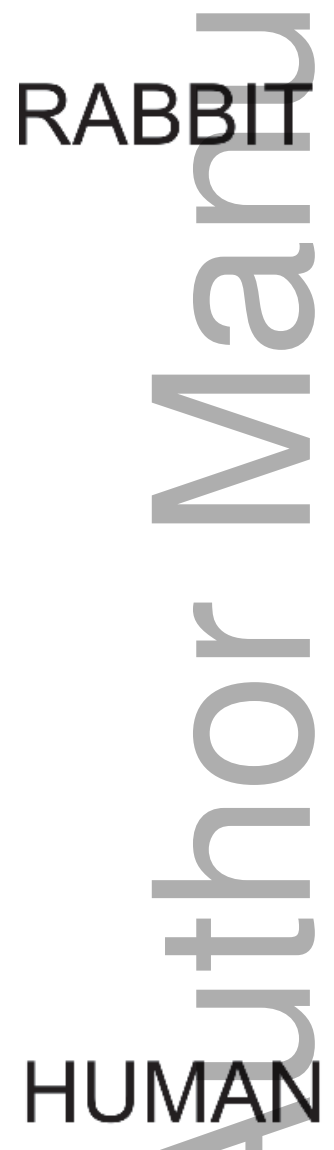

This article is protected by copyright. All rights reserved

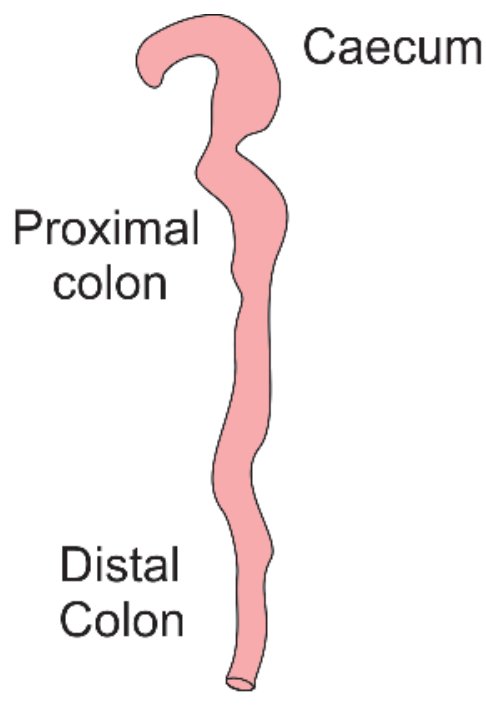

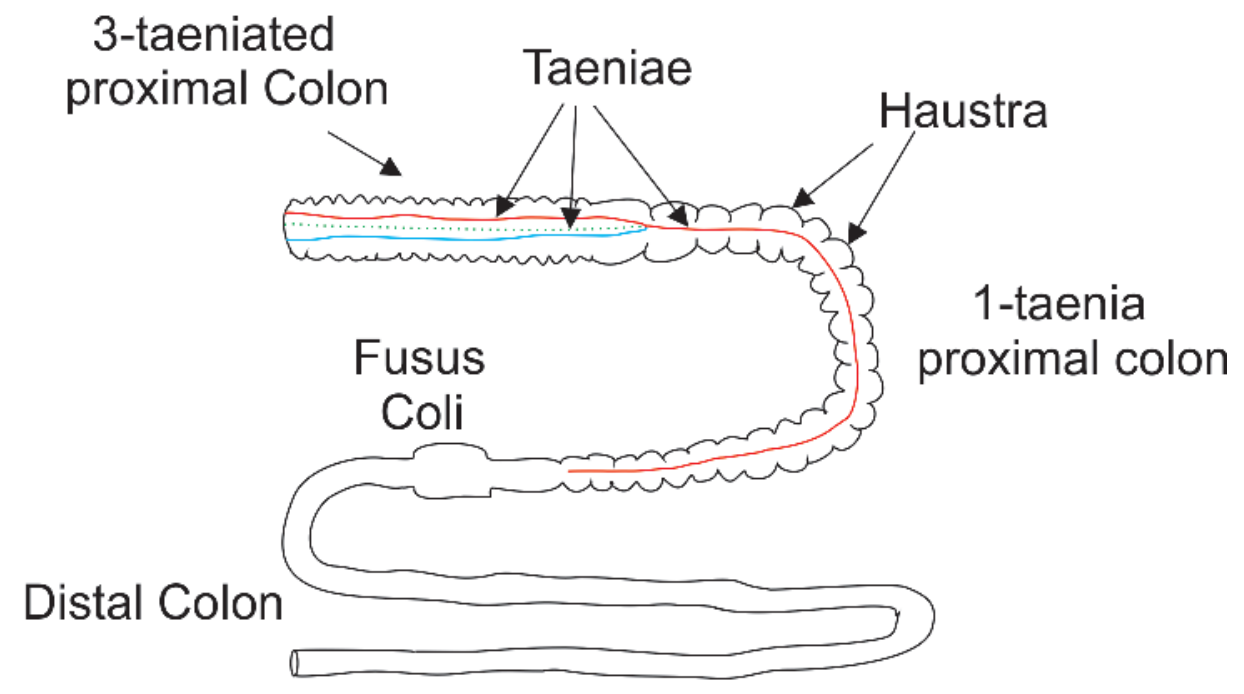

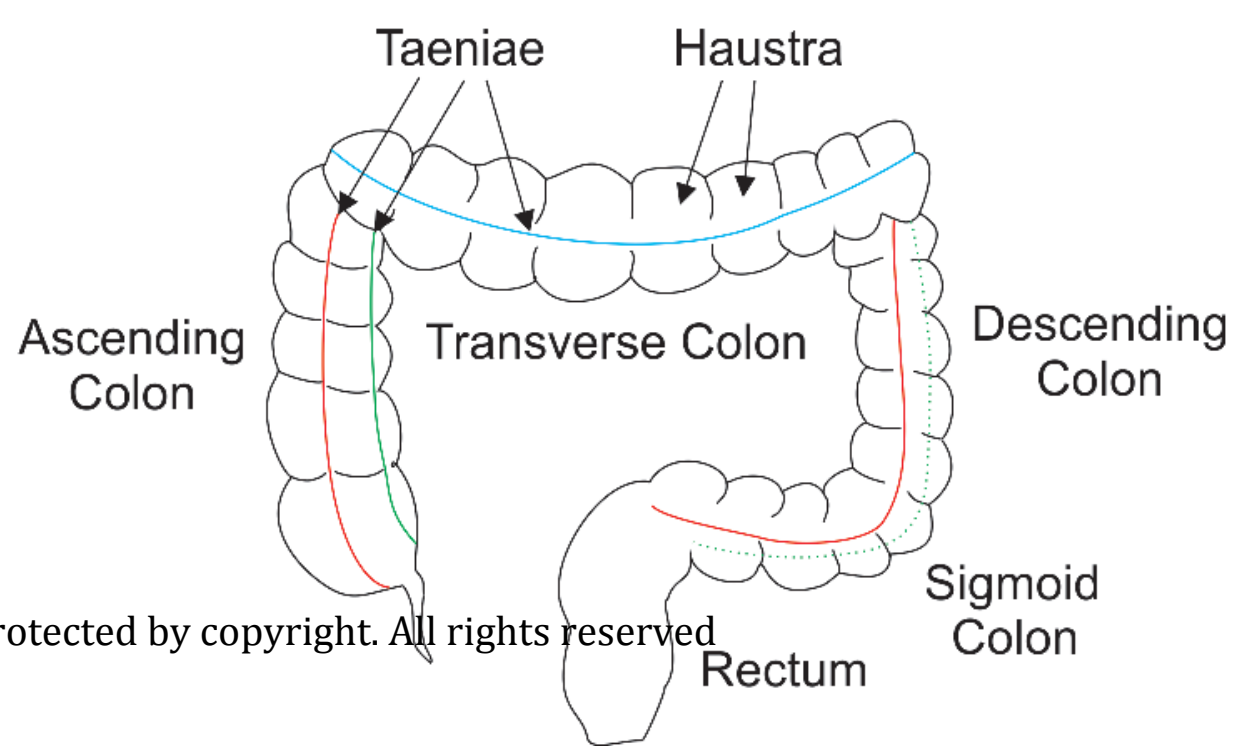




\section{University Library}

\section{- M M I E E R VA A gateway to Melbourne's research publications}

Minerva Access is the Institutional Repository of The University of Melbourne

Author/s:

Gwynne, RM;Bornstein, JC

Title:

Luminal 5-HT4 receptors-A successful target for prokinetic actions

Date:

2019-10-01

Citation:

Gwynne, R. M. \& Bornstein, J. C. (2019). Luminal 5-HT4 receptors-A successful target for prokinetic actions. NEUROGASTROENTEROLOGY AND MOTILITY, 31 (10), https:// doi.org/10.1111/nmo.13708.

Persistent Link:

http://hdl.handle.net/11343/286422 